\title{
Belowground competition in a broad-leaved temperate mixed forest: pattern analysis and experiments in a four-species stand
}

\author{
Boris Rewald · Christoph Leuschner
}

Received: 7 January 2008/Revised: 11 December 2008 / Accepted: 30 January 2009/Published online: 21 April 2009

(C) The Author(s) 2009. This article is published with open access at Springerlink.com

\begin{abstract}
We investigated fine root biomass and distribution patterns in a species-rich temperate CarpinusQuercus-Fagus-Tilia forest and searched for experimental evidence of symmetry or asymmetry in belowground competition. We conducted extensive root coring and applied the recently introduced in situ-root growth chamber technique for quantifying fine root growth under experimentally altered intra- and interspecific root neighbourhoods in the intact stand. In $75 \%$ of all soil cores, fine roots of more than two tree species were present indicating a broad overlap of the root systems of neighbouring trees. Quercus trees had more than ten times less fine root biomass in relation to aboveground biomass or productivity (stem growth) and a much higher leaf area index/root area index ratio than Carpinus, Fagus and Tilia trees. The root growth chamber experiments indicated a high belowground competitive ability of Fagus in interspecific interactions, but a low one of Quercus. We conclude that (1) interspecific root competition is ubiquitous in this mixed stand, (2) root competition between trees can be clearly asymmetric, and (3) tree species may be ranked according to their belowground competitive ability. Fagus was found to be the most successful species in belowground competition which matches with its superiority in aboveground competition in this forest community.
\end{abstract}

Keywords Asymmetric belowground competition Central Germany · European beech · Fine root biomass .

Communicated by J. Bauhus.

B. Rewald · C. Leuschner $(\square)$

Plant Ecology, University of Göttingen,

Untere Karspüle 2, 37073 Göttingen, Germany

e-mail: cleusch@uni-goettingen.de
Root distribution · Hornbeam · Linden ·

Mixed species forest $\cdot$ Sessile oak

\section{Introduction}

A bulk of experimental and observational studies have provided convincing evidence that root competition is an important structuring force in many, if not most, terrestrial plant communities (Wilson 1988; Coomes and Grubb 2000). Current research focuses on the importance of root competition relative to other factors in determining growth and survival of plants and in affecting the diversity and species composition of plant communities (e.g. Rajaniemi et al. 2003; Ludwig et al. 2004). Because the mode of competition substantially influences population and community dynamics (e.g. Łomnicki 1980; Yokozawa et al. 1998; Aikio and Pakkasmaa 2003), there is a vital debate as to whether belowground competition is symmetric or asymmetric (de Kroon et al. 2003; Schenk 2006). Most experimental evidence suggests that soil resource acquisition by root systems of competing plants tends to be proportional to their sizes ('symmetric'; e.g. Weiner et al. 1997; Cahill and Casper 2000). In contrast to light competition, larger root systems per se cannot simply preempt nutrients or water at the expense of smaller plants. However, most of these results were obtained under artificial, homogeneous soil conditions (e.g. Hutchings and John 2004). It has been suggested that the picture of symmetric competition belowground may not be valid in patchy natural environments (e.g. Jackson and Caldwell 1993), where larger and faster growing root systems could exploit resources more completely (Campbell et al. 1991; Van Lear and Kapeluck 1995; Schwinning and Weiner 1998). Thus, the outcome of belowground competition in mixed 
stands may largely depend on the rate and degree as to which different species can access temporal or spatial resource patches in the soil (Thomas and Weiner 1989). In any case, experimental evidence for asymmetric belowground competition is still scarce (Blair 2001; Rajaniemi 2003; von Wettberg and Weiner 2003).

A second topic able to change our perception of belowground competition is the search for organic compounds released in root-root and root-soil interactions (e.g. Bais et al. 2003; Bonanomi et al. 2005; Falik et al. 2003). Chemical signals, yet unknown recognition systems in roots, and indirect root interactions involving other soil organisms may play an important role in the belowground interaction between tree root systems (Schenk 2006). Competition between roots of the same individual will lower resource use efficiency and possibly may reduce plant fitness (Schenk 2006). Indeed, roots have been found to avoid competition with roots of the same plant (Holzapfel and Alpert 2003; Gruntman and Novoplansky 2004; Falik et al. 2005). On the other hand, a plant may increase its fitness by growing roots into soil shared with a competitor, allowing it to acquire resources from that space and also to decrease the competitors' fitness by reducing its resource supply (Robinson et al. 1999).

Various studies found a certain degree of niche partitioning in terms of rooting depth and placing of roots, root dynamics and resource acquisition strategies in mixed stands of herbs and grasses (Parrish and Bazzaz 1976; Mamolos et al. 1995; Nobel 1997; Fargione and Tilman 2005). Belowground interactions among woody plants have mostly been studied in agroforestry systems (Nambiar and Sands 1993). In forests, manipulative studies have mainly focused on root competition between adult trees and forest herbs or tree seedlings (Coomes and Grubb 2000; Barberis and Tanner 2005). Therefore, the significance of root competition between mature trees in intact stands is scarce, and the importance of root competition for tree growth, vitality and species coexistence in mixed forests is poorly understood. This is mainly a consequence of difficult access to the root system of trees and the lack of adequate techniques for studying root competition between trees experimentally.
Here, we present the results of a combined observational and experimental study in a Carpinus-Quercus-FagusTilia temperate mixed forest which investigated the abundance and horizontal distribution, and the relative growth rate (RGR) of fine roots in different competitive neighbourhoods.

Study aims were (1) to relate aboveground structure [leaf area index (LAI), stem density, basal area, stem growth] to belowground structure [fine root biomass and root area index (RAI)] in the four coexisting tree species, (2) to quantify the extent of root system overlap, (3) to assess the evidence for symmetry or asymmetry in fine root competition, and (4) to attempt a ranking of the four species with respect to belowground competitive ability in this mixed stand. We tested the hypotheses that (1) trees with a large aboveground biomass have a roughly proportional biomass belowground, (2) tree root systems are spatially segregated, i.e. territorial in the sense of Schenk et al. (1999), and (3) belowground competition is symmetric in forests.

\section{Methods}

Study site

The study was carried out in 2002 in a four-species mixed forest consisting of 120- to 130-year-old Fagus sylvatica L. (European beech) and Quercus petraea (MATT.) LiEBL. (Sessile oak) trees, and of 70- to 90-year-old Tilia cordata MiLl. (linden) and Carpinus betulus L. (hornbeam) trees in the Ziegelrodaer Forst south of the city of Eisleben in Saxony-Anhalt, Central Germany $\left(51^{\circ} 25^{\prime} \mathrm{N}, 11^{\circ} 31^{\prime} \mathrm{E}\right)$. Forty-seven per cent of the tree individuals (diameter at breast height: $\mathrm{DBH} \geq 7 \mathrm{~cm}$ ) belonged to Carpinus, $40 \%$ to Quercus, $10 \%$ to Fagus and 3\% to Tilia (Table 1). Located in the transition zone between the sub-oceanic and subcontinental regions of Central Europe, the stand represents a community which is intermediate between a beech forest on eutrophic Cambisol (Galio-Fagetum community after Ellenberg, 1996) and an oak-hornbeam-linden forest

Table 1 Stand structural characteristics of the Carpinus, Fagus, Quercus and Tilia trees (DBH $\geq 7 \mathrm{~cm})$ in the 0.37 ha study plot

\begin{tabular}{lccccc}
\hline & Stem density $\left(\mathrm{n} \mathrm{ha}^{-1}\right)$ & Mean DBH $(\mathrm{cm})$ & Mean tree height $(\mathrm{m})$ & Stem basal area $\left(\mathrm{m}^{2} \mathrm{ha}^{-1}\right)$ & Leaf $^{2}$ \\
\hline Carpinus & 166 & $23.0 \pm 0.9 \mathrm{a}$ & $19.0 \pm 0.6 \mathrm{a}$ & 8.6 & $1.7 \pm 0.1 \mathrm{a}$ \\
Fagus & 36 & $46.2 \pm 2.5 \mathrm{~b}$ & $30.1 \pm 0.8 \mathrm{~b}$ & 6.6 & $2.3 \pm 0.1 \mathrm{~b}$ \\
Quercus & 140 & $39.7 \pm 0.8 \mathrm{~b}$ & $27.9 \pm 0.2 \mathrm{~b}$ & 18.3 & $3.3 \pm 0.1 \mathrm{c}$ \\
Tilia & 10 & $39.0 \pm 2.9 \mathrm{ab}$ & $26.1 \pm 1.1 \mathrm{ab}$ & 1.3 & $0.5 \pm 0.1 \mathrm{~d}$ \\
Stand total & 352 & - & - & 34.8 & $7.8 \pm 0.2$ \\
\hline
\end{tabular}

Significant differences between the species are indicated by different letters (mean \pm SE; DBH and leaf area index: $U$ test after Mann and Whitney; tree height: Scheffé test, $P<0.05$ ) 
(Tilio-Carpinetum). The forest has been managed with the prime goal to produce Quercus logs in the past centuries. A substantial reduction in management intensity in the last three decades favoured the regrowth of Carpinus which now forms a second tree layer under the upper canopy of Quercus and Fagus trees. Total stem density was $352 \mathrm{ha}^{-1}$ (all stems with $\mathrm{DBH} \geq 7 \mathrm{~cm}$ ) with Carpinus contributing most of the thinner stems. Fagus, Quercus and Tilia did not differ significantly with respect to DBH $(39-46 \mathrm{~cm})$ and mean tree height $(26-30 \mathrm{~m})$, whereas the Carpinus trees were, on average, less tall and had a lower DBH (Table 1). While a shrub layer was nearly absent $(<2 \%$ cover), about $10 \%$ of the forest floor was occupied by forest herbs (Anemone nemorosa L., Stellaria holostea L., Athyrium filix-femina (L.) RотH and other species).

Mean annual precipitation was $462 \mathrm{~mm}$ at the nearby weather station of Allstedt; it is assumed that the study plot at a somewhat higher elevation received about $520 \mathrm{~mm} \mathrm{year}^{-1}$ (Schipka 2002) with approximately 55\% of the annual precipitation falling from May to September (300 $\mathrm{mm}$ in the study year 2002). The mean annual temperature was $8.6^{\circ} \mathrm{C}$. The soils were meso- to eutrophic Cambisols $\left(\mathrm{pH}\left(\mathrm{H}_{2} \mathrm{O}\right): 4.3-4.4\right.$; base saturation about $40 \%$ in the topsoil) derived from Triassic sandstone (Upper Bunter) covered by a thin layer of Pleistocene eolic loess deposits. Atop of the mineral soil, a thin (5-30 mm) layer of ectorganic material (humus form: mull) was present. The groundwater horizon was far below the rooting zone.

Selection criteria for the study plot were (1) absence of canopy gaps, (2) a representative tree species composition with respect to the forest community, and (3) only minor soil disturbance by wild boar. A plot of 0.37 ha $(45 \times 92 \mathrm{~m})$, which fulfilled these criteria, was selected and fenced, and all stems $\geq 7 \mathrm{~cm} \mathrm{DBH}$ were mapped. Diameter at breast height was measured with dendrometer tapes at $1.3 \mathrm{~m}$ height, tree height with an ultrasonic Vertex III height meter (Haglöf, Sweden). For monitoring stem increment, 4-12 stems per species were instrumented with dendrometer tapes and read seven times during a period of 12 months. The stems used for increment measurement were selected in direct proximity to the root coring transects (see below); the stems represented the most abundant diameter classes of the species in the stand. We used allometric regressions based on $\mathrm{DBH}$ and stem form to estimate annual stem growth of the four species using the single-tree modelling software BWinPro (Nagel and Schmidt 2006). The LAI was measured by litter sampling in autumn. Litter fall was collected with 30 litter buckets of $0.29 \mathrm{~m}^{2}$ aperture placed in the plot at random distances along the root coring transects (see below). The material was sorted into leaves and non-leaf material (including bark, twigs and reproductive organs). Twenty leaves per bucket were selected by random and analysed individually for their area with the software WinFolia 2001a (Régent, Quebec, Canada).

Analysis of fine root mass, morphology and distribution

Soil coring and associated fine root analysis was conducted for three purposes, (1) to estimate the root biomass and necromass of the four tree species in the stand, (2) to analyse the vertical and horizontal fine root distribution by species, and (3) to compare the four coexisting species with respect to fine root morphological properties.

Fine root $(d \leq 2 \mathrm{~mm})$ sampling was conducted in June 2002 with sharp soil corers $(d=35 \mathrm{~mm})$ that were manually driven into the topsoil to a depth of $25 \mathrm{~cm}$. Coring was conducted at 60 locations that were selected by random on three transects of $30 \mathrm{~m}$ length (20 locations per transect). The transects were demarcated at a distance of about $5 \mathrm{~m}$ to each other in the north-western part of the study plot where all four tree species occurred in quantities corresponding to their presence in the entire plot, where the mean stem distance was about $7 \mathrm{~m}$ and no marked clumping of stems occurred (data not shown). A clumping of stems would have complicated a spatial analysis of fine root mass in the stand. The exact position of the root coring locations in the plot was recorded with the aim to analyse the dependence of root biomass on the distance to the closest stem, tree species identity, and basal area of the surrounding stems. In the analysis of the relationship between belowground and aboveground biomass structure, all stems within a radius of $5 \mathrm{~m}$ around a coring location were considered.

The soil cores were sliced into organic layer, upper $(0-10 \mathrm{~cm})$ and lower $(10-20 \mathrm{~cm})$ mineral soil horizons, transferred to plastic bags, sealed, and transported to the laboratory where the processing of the stored samples $\left(4^{\circ} \mathrm{C}\right)$ took place within 4 weeks (Tierney and Fahey 2001). We restricted root coring to the organic layer and the 0-20 cm layer of the mineral soil, since earlier investigations in the Ziegelrodaer Forst had shown that fine root biomass decreases exponentially with soil depth and that the $0-20 \mathrm{~cm}$ section of the soil profile contained about $60 \%$ of the total fine root biomass of the stand (Hertel 1999).

The samples were cleaned from soil using a water jet and a $0.25 \mathrm{~mm}$ sieve. Fine roots of the four tree species were separated under the binocular $(16-40 \times)$ according to colour, periderm surface structure and ramification. Hertel (1999), Hölscher et al. (2002) and Korn (2004) developed a preliminary key for distinguishing fine roots of Fagus, Quercus, Carpinus and Tilia based on a set of morphological criteria, which was applied here. Live (biomass) and dead rootlets (necromass) were distinguished by colour, root elasticity and the degree of cohesion of cortex, periderm and stele. A non-turgid cortex and stele, an 
air-filled stele, or the complete loss of the stele and cortex with only the periderm being present, were used as indicators of root death (Leuschner et al. 2004). Herb roots occurred only at very low densities in the stand; they were discarded. Large fine root fragments (length $\geq 10 \mathrm{~mm}$ ) were extracted by hand, smaller fragments were determined in sub-samples ( $n=8$ per soil horizon) by spreading the remaining sieve content on a piece of filter paper $\left(730 \mathrm{~cm}^{2}\right.$ ) with 36 squares marked on it (Van Praag et al. 1988). Six of the squares were randomly selected and analysed in a time-consuming procedure under the binocular for even smallest fine root fragments. The mass of small fragments was then extrapolated to all samples by quantifying the ratio between large and small root fragments in a sub-sample. All samples were oven-dried (48 h, $70^{\circ} \mathrm{C}$ ) to constant weight.

The root mass data were expressed per ground area $\left(\mathrm{g} \mathrm{m}^{-2}\right.$ to a depth of $20 \mathrm{~cm}$ ) and as biomass/necromass ratio for each tree species. Coring locations, where all surrounding stems within a $5 \mathrm{~m}$ radius belonged to one species, were termed 'mono-specific coring locations'; 'multi-species coring locations' were surrounded by stems of two to four tree species.

For investigating root morphology, 29-49 fresh fine root samples per species and soil horizon were extracted and analysed for specific fine root surface area (SRA, in $\mathrm{cm}^{2} \mathrm{~g}^{-1}$; only fraction $\leq 2 \mathrm{~mm}$ in diameter considered) using a flat-bed scanner and the image analysis program WinRhizo 2002a (Régent, Quebec, Canada). By multiplying SRA with fine root biomass in the horizons, a fine RAI (in $\mathrm{m}^{2}$ per $\mathrm{m}^{2}$ ground area and $20 \mathrm{~cm}$ depth) was obtained. The specific abundance of live fine root tips (n per mg root dry mass) was also counted under a stereo-microscope.

\section{Root chamber experiments on fine root competition}

Hertel and Leuschner (2006) introduced the in situ-root growth chamber technique for monitoring fine root growth of trees in the soil of mature forests under conditions of manipulated root neighbourhoods. This approach allows conducting replicated experiments on competitive interactions between tree fine roots under field conditions in intact forests. Our chambers partly resemble the root chambers developed by Mahall and Callaway (1991), Espeleta et al. (1998) and Escamilla and Comerford (1998) for studying nutrient depletion, root communication or the functioning of mycorrhizal roots in the rhizosphere. We applied this technique for quantifying competition between fine roots of all four species (interspecific competition) and compared the results with the outcome of intraspecific competition treatments. The technique and its application are described in detail in Hertel and Leuschner (2006). Briefly, 335 root growth chambers manufactured from opaque PVC plates with a volume of $189 \mathrm{~cm}^{3}(90 \times 70 \times 30 \mathrm{~mm}$ length, height and width) were used in the stand. The chamber's front and back sides were perforated with 36 holes $(d=1 \mathrm{~mm})$ each, and the top and bottom consisted of plastic gauze $(d=1.5 \mathrm{~mm})$ to permit sufficient water percolation and gas exchange but to prevent root ingrowth from the surrounding soil.

We investigated ten different competitive root interactions (six possible interspecific interactions between each two species, four intraspecific interactions) by placing two terminal fine roots in each chamber and exposing them for 180-210 days in the topsoil in situ. The chambers were covered by a layer of soil or litter. Live terminal fine roots were carefully uncovered in the uppermost soil with a pair of tweezers and small spoons, and inserted through one of the two openings $(d=6.5 \mathrm{~mm})$ at the two opposite side walls. By this procedure, the mycorrhizal mycelium in the rhizosphere was cut but the terminal finest roots and their root tips remained intact and typically continued growth within a few weeks inside the chamber (Hertel and Leuschner 2006). After 6 months of exposure in the chambers, the majority of roots were intensively re-infected by mycorrhizal fungi and showed vital growth. The roots selected for study had a diameter at the point of insertion of $2 \mathrm{~mm}$; approximately $30 \mathrm{~mm}$ of the terminal root section was enclosed in the chamber. Since the two root endings partly overlapped in the chamber, competitive interactions must have occurred in the experiments. The species identity of the roots was detected in situ from periderm morphology and colour as described above. In the case of experiments on interspecific root competition, the study objects were fine roots of two different species; intraspecific competition was investigated with two conspecific roots in a chamber. The chambers were filled with root-free mineral soil extracted from the direct vicinity and the roots were carefully embedded in this substrate which more or less resembled the undisturbed soil environment in the stand.

We attempted to accommodate each of the ten studied interaction types with at least 30 chambers to allow for a statistical analysis of the data. At the date of harvest, the branch roots were cut at the insertion holes, carefully extracted from the chamber and their dry mass $\left(48 \mathrm{~h}, 70^{\circ} \mathrm{C}\right)$ and length increment were determined in the laboratory. Root performance was assessed as root RGR (in $\mathrm{mg} \mathrm{g}^{-1}$ day $^{-1}$ ) between insertion date and date of harvest. The root for which RGR was calculated was termed 'target species', whereas the second root present was termed 'competitor'. The initial biomass of the two inserted fine roots was estimated non-destructively by photographing the root in front of a graph paper at the beginning of the experiment and calculating root length/dry mass relationships from root samples taken close to the chambers. 
For quantifying a species' ability to compete successfully with the roots of other tree species for soil space and soil resources, we defined a competitive ability index (CA) which uses fine root RGR as a fitness parameter in the belowground compartment. We assumed that root growth is closely linked to an increase in absorbing surface area and thus to a growing nutrient and water absorption capacity of the fine root system. A species' RGR in interspecific interaction (two-species chambers, $\mathrm{RGR}_{\text {mix }}$ ) was contrasted with its RGR in intraspecific interaction (singlespecies chambers, $\mathrm{RGR}_{\text {mono }}$ ) with

$\mathrm{CA}=\left(\mathrm{RGR}_{\text {mix }}-\mathrm{RGR}_{\text {mono }}\right) \times \mathrm{RGR}_{\text {mono }}^{-1}$.

Positive CA values stand for a better root growth with an allospecific root than with a conspecific one. For assessing the competitive ability of a tree species in all possible interspecific interactions in this four-species stand, all three $\mathrm{CA}$ values of a species were averaged. Similar CA values of two competing species were interpreted as an indication of a quasi-symmetric competitive interaction, irrespective of the absolute size of RGR of the two species. On the other hand, we assumed the larger the species differences in CA, the more asymmetric the interaction to be.

Using root RGR as criterion to assess belowground competitive ability follows the general practice in competition experiments with herbaceous pot-grown plants (Grace 1995). This species-centred approach of belowground competitive ability contrasts with the concept adopted by Schenk (2006) who focuses on the communitylevel consequences of belowground competition by defining root competition to be 'a reduction in the availability of a soil resource to roots that is caused by other roots'.

We were not able to reach a balanced experimental design in the root chamber study because the fine roots of the four species occurred at different abundances in the soil. Since root species identification in the field was erroneous in various cases, species identification was verified under a binocular $(16-40 \times)$ at the date of harvest. This resulted in certain deviations from the planned scheme of interaction types to be investigated. Thus, several species combinations were represented with only a few chambers, while others could be accommodated with more than 30 replicates because the root species combination was particularly abundant. Furthermore, it turned out upon harvest that, in about $5 \%$ of the chambers, the roots had not grown at all, or the experiment was disturbed by the ingrowth of additional fine roots from the surrounding soil (3\%). Possible causes of zero root growth were root damage during the insertion process, assumed low vitality of the roots at the start of the experiment, or other unknown factors. Therefore, chambers with RGRs $<0.001 \mathrm{mg} \mathrm{g}^{-1}$ day $^{-1}$ were excluded from the analysis.
Statistical analysis

All data sets were tested for Gaussian distribution with a Shapiro-Wilk test. We used a parametric Scheffé's multiple comparison procedure to test for significant differences in tree height and fine root biomass among the four species. A non-parametric Mann and Whitney (Wilcoxon) twosample test was used to determine if (1) tree species had different DBH means, (2) root growth rates were different in the root chamber treatments, (3) the species differed with respect to fine root morphology, and (4) the species differed in their relative competitive abilities. These calculations were conducted with the SAS System for Windows 8.02 (SAS Institute, Cary, NC, USA). Linear and non-linear regressions were calculated with the program Xact 8.03 (SciLab, Hamburg, Germany).

\section{Results}

Aboveground forest structure and productivity of the four tree species

The four-species mixed stand in the Ziegelrodaer Forst showed very different stem numbers and basal areas for Carpinus, Fagus, Quercus and Tilia. Quercus was the most abundant tree species with $40 \%$ of the stems and $53 \%$ of the basal area in this stand, followed by Carpinus (stems: 47\%, basal area: 25\%) and Fagus (10 and 19\%, respectively). Tilia contributed less than $4 \%$ of the stems and of the basal area (Table 1). In contrast, relative basal area increment (in \%o of the existing basal area) in the period January to September 2002 tended to be higher in Fagus than in all other species (Fig. 1, only the difference FagusTilia significant), and thus was not related to a species' abundance in the stand. The LAI was significantly different between the four species; LAI of all trees in the stand totalled at $7.8 \mathrm{~m}^{2} \mathrm{~m}^{-2}$ (Table 1).

Fine root mass of the four species

No significant relationship between a species' basal area and its fine root biomass existed in the stand. Quercus with $53 \%$ of the basal area and an annual stem wood production of $1.2 \mathrm{Mg} \mathrm{ha}^{-1}$ contributed only $11 \%$ of the stand total of fine root biomass, whereas Fagus (19\% of basal area) and Carpinus (25\%) with 0.4 and $0.1 \mathrm{Mg} \mathrm{ha}^{-1}$ of stem wood production were over-represented in root biomass (32 and 51\%, respectively, Fig. 2). Relating fine root biomass to stem increment yielded quotients of 150 $1,000 \mathrm{~g}$ root biomass per $\mathrm{Mg} \mathrm{ha}^{-1}$ of stem increment in Carpinus, Fagus and Tilia, but only $17 \mathrm{~g}$ per $\mathrm{Mg} \mathrm{ha}^{-1}$ in Quercus. 


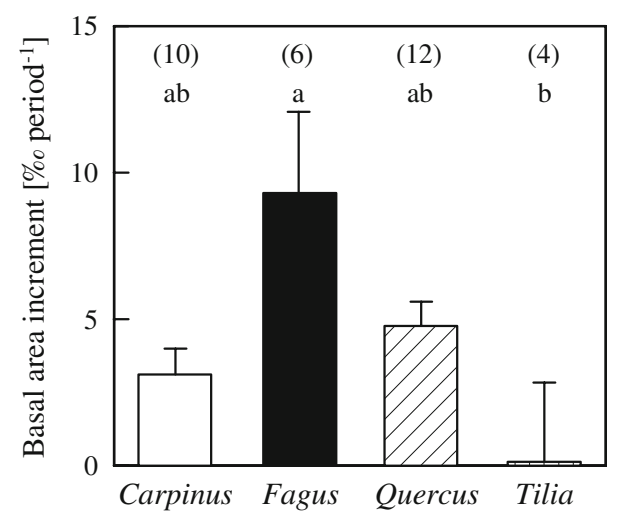

Fig. 1 Mean basal area increment (in \%o of the existing basal area) in the period January-September 2002 of the four tree species in the study plot (mean $+\mathrm{SE} ; n=4-12$ trees per species). Significant differences between the species are indicated by different letters $(U$ test after Mann and Whitney, $P<0.05$ )

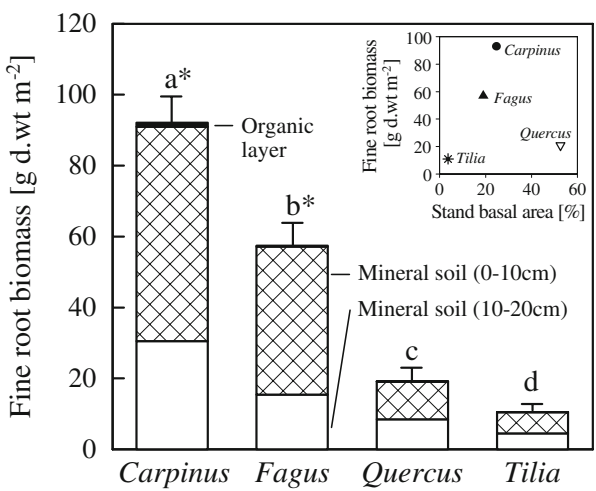

Fig. 2 Fine root biomass of the four tree species in the organic layer and two mineral soil horizons $(0-10$ and $10-20 \mathrm{~cm})$ of the study plot $(n=59$, mean $+\mathrm{SE})$. Inlet: relationship between relative stand basal area and fine root biomass for the four species in the stand. Significant differences between the species are indicated by different letters $(U$ test after Mann and Whitney, $P<0.05$ ). Asterisks denote significant differences between upper and lower mineral soil horizon

We found twice as much fine root necromass in the profile to $20 \mathrm{~cm}$ depth than root biomass with Carpinus contributing by far the largest proportion $(>50 \%)$ of dead roots (Table 2). Fagus had a significantly higher biomass/ necromass ratio (0.84) than Tilia, Carpinus and Quercus $(0.45-0.79)$

Fine root morphology was not significantly different between the four species with respect to specific root surface area (SRA), the relative proportion of finest roots $(\leq 1 \mathrm{~mm}$ in diameter) in fine root biomass, and specific root tip frequency (Table 3). However, Tilia tended to have a higher SRA, and Fagus and Tilia a lower root tip frequency than the other species. The fine RAI of all trees in the stand totalled at $4.5 \mathrm{~m}^{2} \mathrm{~m}^{-2}$ (profile to $20 \mathrm{~cm}$ soil depth) with particularly large contributions by Carpinus and Fagus (Table 2).
Table 2 Necromass, biomass:necromass ratio, and root area index (RAI) of fine roots of the four tree species in soil profiles (organic layer and $0-20 \mathrm{~cm}$ of mineral soil) of the study plot (mean $\pm \mathrm{SE}$, $n=59)$

\begin{tabular}{lcll}
\hline & $\begin{array}{l}\text { Fine root } \\
\text { necromass } \\
\left(\mathrm{g} \mathrm{DW} \mathrm{m}^{-2}\right)\end{array}$ & $\begin{array}{l}\text { Fine root } \\
\text { biomass: } \\
\text { necromass } \\
\text { ratio }\end{array}$ & $\begin{array}{l}\text { Fine root } \\
\text { area index } \\
\left(\mathrm{m}^{2} \mathrm{~m}^{-2}\right)\end{array}$ \\
\hline Carpinus & $190.4 \pm 16.8 \mathrm{a}$ & $0.45 \pm 0.03 \mathrm{~b}$ & $2.4 \pm 0.4 \mathrm{a}$ \\
Fagus & $94.4 \pm 19.2 \mathrm{~b}$ & $0.84 \pm 0.08 \mathrm{a}$ & $1.4 \pm 0.3 \mathrm{~b}$ \\
Quercus & $57.0 \pm 4.1 \mathrm{~b}$ & $0.54 \pm 0.10 \mathrm{~b}$ & $0.5 \pm 0.3 \mathrm{c}$ \\
Tilia & $21.4 \pm 5.7 \mathrm{c}$ & $0.79 \pm 0.16 \mathrm{~b}$ & $0.2 \pm 0.2 \mathrm{~d}$ \\
\hline
\end{tabular}

Significant differences between the species are indicated by different letters ( $U$ test after Mann and Whitney, $P<0.05$ )

Table 3 Proportion of finest roots (diameter $d \leq 1 \mathrm{~mm}$ ) in fine root biomass $(d \leq 2 \mathrm{~mm})$, specific fine root surface area (SRA), and specific root tip frequency of the four tree species in the mineral soil (0-20 cm; mean \pm SE; $n=$ sample size $)$

\begin{tabular}{lllll}
\hline & $n$ & $\begin{array}{l}\text { Proportion } \\
\text { of finest } \\
\text { roots }(\%)\end{array}$ & $\begin{array}{l}\text { Specific } \\
\text { root area } \\
\left(\mathrm{cm}^{2} \mathrm{~g}^{-1}\right)\end{array}$ & $\begin{array}{l}\text { Specific } \\
\text { root tip } \\
\text { frequency } \\
\left(\mathrm{n} \mathrm{mg}^{-1}\right)\end{array}$ \\
\hline Carpinus & 44 & $88.2 \pm 1.8 \mathrm{a}$ & $349.2 \pm 28.8 \mathrm{a}$ & $26 \pm 4 \mathrm{a}$ \\
Fagus & 49 & $90.2 \pm 2.1 \mathrm{a}$ & $315.4 \pm 19.0 \mathrm{a}$ & $17 \pm 2 \mathrm{a}$ \\
Quercus & 36 & $95.7 \pm 1.4 \mathrm{a}$ & $325.5 \pm 39.1 \mathrm{a}$ & $23 \pm 4 \mathrm{a}$ \\
Tilia & 29 & $90.0 \pm 3.6 \mathrm{a}$ & $415.9 \pm 73.3 \mathrm{a}$ & $18 \pm 5 \mathrm{a}$ \\
\hline
\end{tabular}

Different letters indicate significant differences between the species ( $U$ test after Mann and Whitney, $P<0.05$ )

Spatial distribution of fine roots and overlap among different species

The identification of fine roots by species allowed us to analyse species-specific fine root abundances in the upper soil horizons in horizontal and vertical direction in the soil of the mixed stand. All species exhibited horizontal root distribution patterns that were more or less stem-centred with the highest biomass of a species regularly occurring at distances of 2-5 m around the stem (Fig. 3). Species-specific fine root density decreased more rapidly with stem distance in Carpinus and Fagus, which generally had higher fine root biomasses in the stand, than in Quercus and Tilia, species with a comparably low density. The maximum horizontal extension of fine roots was estimated at $15 \mathrm{~m}$ for Tilia; in the other three species, we were not able to detect root system radii $>7-12 \mathrm{~m}$ because distances between conspecific stems were shorter than in the rare species Tilia.

The $0-20 \mathrm{~cm}$ mineral soil was densely explored by tree fine roots, and the root systems of the four species 


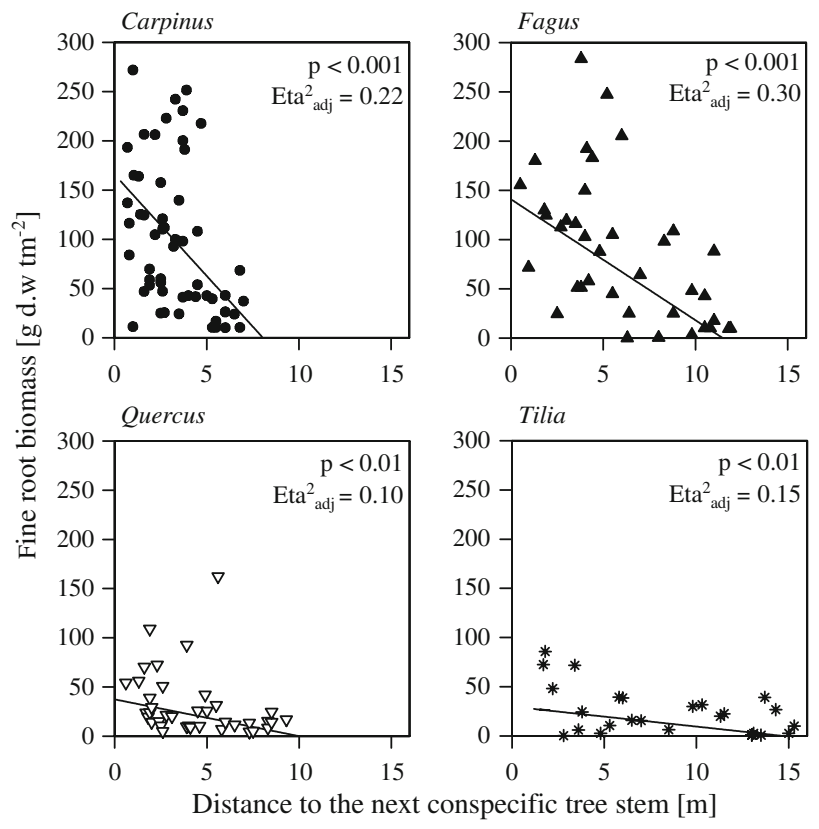

Fig. 3 Relation between cumulative fine root biomass of a species in the soil (organic layer and $0-20 \mathrm{~cm}$ of mineral soil) of the study plot and distance to the nearest conspecific stem ( $n=59$ soil samples)

overlapped extensively. More than 50\% of all investigated soil samples contained roots of two species; about $25 \%$ were explored by three or four species. Only one species was present in about $25 \%$ of the samples. The thin organic layer (5-30 mm in depth) contained only roots of Fagus and Carpinus, the two species with the largest total fine root biomass in the stand (Table 4).

Apparent neighbour effects on fine root biomass

Different root abundances of a target species in forest patches, in which either conspecific or allospecific tree species were dominant aboveground, may give hints on a species' belowground competitive ability in interspecific interactions. For each of the four species, we compared the fine root biomass in forest patches, where either all surrounding trees in a $5 \mathrm{~m}$ radius were conspecific $\left(M_{\text {mono }}\right.$,

Table 4 Relative frequency of soil samples containing fine roots of $1-4$ tree species (or no roots at all) in three soil layers (in per cent; $n=59$ )

\begin{tabular}{lccc}
\hline $\begin{array}{l}\text { No. of tree species } \\
\text { present with } \\
\text { their fine roots }\end{array}$ & $\begin{array}{l}\text { Organic } \\
\text { layer }\end{array}$ & $\begin{array}{l}\text { Mineral soil } \\
(0-10 \mathrm{~cm})\end{array}$ & $\begin{array}{l}\text { Mineral soil } \\
(10-20 \mathrm{~cm})\end{array}$ \\
\hline No fine roots & 59.3 & 0 & 0 \\
1 & 33.9 & 23.4 & 17.2 \\
2 & 6.8 & 48.3 & 60.3 \\
3 & 0 & 23.3 & 15.6 \\
4 & 0 & 5.0 & 6.9 \\
\hline
\end{tabular}

'mono-specific coring locations'), with patches, where part of the trees were allospecific ( $M_{\text {mix }}$, 'multi-species coring locations'). As expected, a species' fine root biomass in the $0-20 \mathrm{~cm}$ profile tended to be higher in the mono-specific coring locations than in the multi-species locations for all four species (Table 5). However, only in the case of Tilia, the $M_{\text {mix }}-M_{\text {mono }}$ difference was large and significant at $P<0.05$. In Quercus, the difference was marginally significant $(P<0.1)$. Carpinus and Fagus showed only non-significant differences in root biomass between monospecific and multi-species coring locations. A large root biomass reduction in the presence of allospecific trees is reflected by small $M_{\text {mix }} / M_{\text {mono }}$ ratios as in Tilia and Quercus (0.16 and 0.48), a small reduction by high ratios as in Carpinus and Fagus (0.84 and 0.81).

In situ-root competition experiments

In the in situ-root growth chamber experiments, Quercus, Tilia and, in part, Carpinus showed highest RGRs of their fine roots when exposed with a conspecific root (the differences in growth rates between intra- and interspecific competition treatments were only partly significant at $P<0.05$, Table 6). Fagus fine roots, in contrast, grew significantly better in the neighbourhood of a Quercus or Carpinus root than in proximity to a conspecific root (the differences in growth rates between intra- and interspecific competition treatments were only partly significant at $P<0.05)$.

The competitive ability index CA, which is defined as fine root RGR of the target species in intraspecific interaction versus interspecific interaction with the three other tree species, showed large differences between the four species and was highest for Fagus $(+0.30)$ and lowest for Quercus (-0.25); Tilia and Carpinus ranked in-between (+0.03 and -0.15 , Fig. 4$)$.

\section{Discussion}

Relationship between aboveground and belowground structures

The fine root systems had a far larger horizontal extension than the corresponding tree crowns in the four-species mixed stand. This observation is in accordance with various other root inventories in forests, orchards and agroforestry systems (e.g. Kochenderfer 1973; Atkinson et al. 1976; Mou et al. 1995; Johnsen et al. 2005). Tilia trees spread their fine roots over an area of about $700 \mathrm{~m}^{2}$ (radius $\approx 15 \mathrm{~m}$ ), which is roughly ten times the size of the crown projection area (data not shown). A much larger size of the root system compared to the crown area was already 
Table 5 Fine root biomass (in $\mathrm{g} \mathrm{DW} \mathrm{m}^{-2}$ ) in soil profiles (organic layer and 0-20 $\mathrm{cm}$ of mineral soil) in soil patches surrounded either by conspecific stems ('mono-specific coring locations') or by one or more allospecific stems ('multi-species coring locations') within a $5 \mathrm{~m}$ radius

\begin{tabular}{llrcrc}
\hline Species & Mono-specific coring locations & $n$ & Multi-species coring locations & $n$ & Multi-species/mono-specific ratio \\
\hline Carpinus & $144.8 \pm 18.9 \mathrm{Aa}$ & 14 & $122.8 \pm 14.9 \mathrm{Aa}$ & 22 & $0.84 \pm 0.10$ \\
Fagus & $149.2 \pm 12.8 \mathrm{ABa}$ & 4 & $121.0 \pm 23.6 \mathrm{Aa}$ & 9 & $0.81 \pm 0.19$ \\
Quercus & $68.3 \pm 14.9 \mathrm{Ba}$ & 5 & $32.8 \pm 11.2 \mathrm{Ba}$ & 14 & $0.48 \pm 0.16$ \\
Tilia & $60.6 \pm 10.0 \mathrm{Ba}$ & 5 & $9.9 \pm 7.4 \mathrm{Bb}$ & 5 & $0.16 \pm 0.13$ \\
\hline
\end{tabular}

The biomass ratio in multi-species to mono-specific locations is given as well. Significant differences between the fine root biomass in monospecific and multi-species locations are indicated by different small letters (Scheffé test, $P<0.05$ ), significant differences between the tree species by different capitals (Scheffé test, $P<0.1$; mean \pm SE; $n=$ sample size)

Table 6 Relative growth rate of fine roots (RGR; $\mathrm{mg} \mathrm{g}^{-1}$ day $^{-1}$ ) of target species (rows) as dependent on the presence of roots of competitors (columns) in in situ-root growth chambers that were exposed for 180-210 days in the topsoil

\begin{tabular}{|c|c|c|c|c|}
\hline \multirow[t]{2}{*}{ Target species } & \multicolumn{4}{|l|}{ Competitor } \\
\hline & Carpinus & Fagus & Quercus & Tilia \\
\hline Carpinus & $1.8 \pm 0.1$ a $(153)$ & $1.6 \pm 0.2 \mathrm{ab}(64)$ & $1.0 \pm 0.2 \mathrm{c}(29)$ & $1.1 \pm 0.2 \mathrm{bc}(35)$ \\
\hline Fagus & $2.0 \pm 0.2 \mathrm{a}(64)$ & $1.1 \pm 0.2$ b $(82)$ & $1.5 \pm 0.5 \mathrm{ab}(16)$ & $0.7 \pm 0.3 \mathrm{~b}(16)$ \\
\hline Quercus & $1.7 \pm 0.3$ a (29) & $2.1 \pm 0.5$ a $(16)$ & $2.4 \pm 0.6$ a (6) & $1.3 \pm 0.7$ a $(5)$ \\
\hline Tilia & $1.6 \pm 0.3 \mathrm{a}(35)$ & $1.5 \pm 0.3 \mathrm{a}(16)$ & $1.8 \pm 0.5$ a (5) & $1.9 \pm 0.7$ a $(65)$ \\
\hline
\end{tabular}

Mixed-species chambers contained fine roots of two species (interspecific competition), single-species chambers two fine roots of the same species (intraspecific competition, in frames). Significant differences in root RGR of a target species in the four treatments are indicated by different letters ( $U$ test after Mann and Whitney, $P<0.05$; mean \pm SE; number of replications given in parentheses)

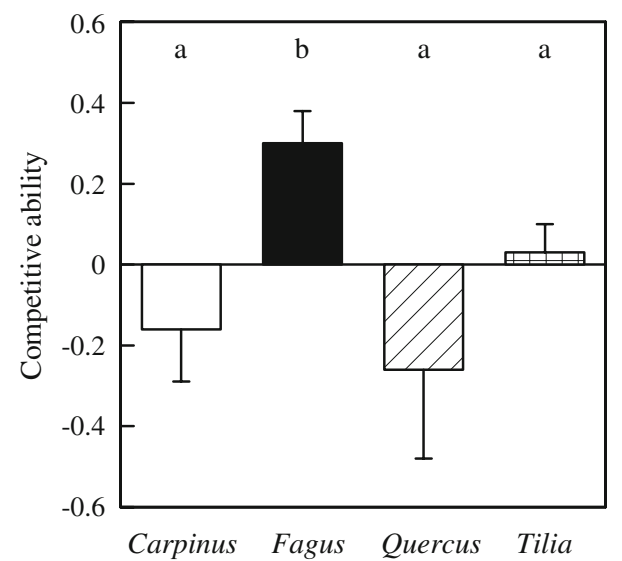

Fig. 4 Competitive ability CA (for definition see text) for interspecific competitive interactions of fine roots in relation to intraspecific interactions in the four tree species according to fine root growth experiments in in situ-root growth chambers. The CA values for all possible three interspecific interactions per species were averaged to obtain a species mean. Different letters indicate significant differences in CA values between the species ( $U$ test after Mann and Whitney, $P<0.05)$. Mean \pm SE for 128, 96, 50, and 56 interspecific chambers of Carpinus, Fagus, Quercus and Tilia, respectively

reported for deciduous trees by Stout (1956) who found a mean ratio of 4.5:1 for crown versus root system area. For Fagus, Quercus and Tilia, we found a gradual decrease in fine root density with increasing stem distance within a radius of $10 \mathrm{~m}$ or more, but not a strict stem-centred distribution pattern as it was observed, for example, in spruce forests by Bédéneau and Auclair (1989) and Nielsen and Mackenthun (1991). Of the species present showed Carpinus the steepest decrease in fine root biomass with increasing stem distance. We assume that the more stemcentred fine root distribution pattern observed in Carpinus is a consequence of the numerous pre-mature hornbeam trees in this stand which are forming a second canopy layer and may not have reached the root system's maximum size in this stand. Given the high degree of root system overlap with $75 \%$ of the soil volume being explored by at least two or three different species, there are no indications of a spatial segregation ('territoriality') of whole fine root systems in this stand as was suggested by Lyford and Wilson (1964), Schenk et al. (1999) and others. Our results, based on soil core analyses, are not precluding root segregation at a millimetre or centimetre scale as reported by Caldwell et al. (1996).

The four tree species differed largely with respect to their presence in terms of fine root biomass and root surface area in the soil volume of the mixed stand. Relating fine root biomass to aboveground structural parameters, Carpinus had a very high fine root biomass in relation to its aboveground biomass and productivity in the stand, followed by Fagus with slightly lower fine root biomass/stem increment biomass (FRB/ST) ratios. In contrast, Quercus was highly under-represented in the belowground 
compartment with more than ten times smaller FRB/ST and FRB/stem biomass ratios than Carpinus. Although fine root biomass does not necessarily reflect belowground productivity, the very large differences in the belowground/ aboveground carbon partitioning patterns between Quercus and the other three species are unexpected because nutrient and water availability in the shared soil volume are imposing similar constraints on the functionality of the root system of the four species in this stand. Other biometric parameters such as the sapwood area/leaf area ratio (Huber value) or the LAI to basal area ratio are also known to differ between coexisting tree species in mixed stands, but they are not different by a factor of ten (Ammer 2003; Burkes et al. 2003).

These apparent tree species differences in carbon allocation patterns may have genetic causes expressing different physiological constitutions, or they can be a consequence of asymmetric interspecific competition, which may lead to a suppression of inferior competitors belowground. Evidence for the second explanation will be assessed in the following.

Evidence of asymmetry in belowground competition

We found two lines of evidence for the existence of asymmetry in belowground competition in this mixed forest, (1) indirect evidence from a comparison of fine root abundances in mono-specific and multi-species patches of the stand, and (2) direct evidence from root growth experiments in contrasting root neighbourhoods using root growth chambers.

Our observation of an over-proportional reduction in fine root biomass of Quercus petraea in species-rich allospecific compared to monospecific stand patches in the Ziegelrodaer forest is supported by other studies in Central Europe. Büttner and Leuschner (1994) and Leuschner et al. (2001) found a 20\% contribution of Quercus fine roots to the stand total of fine root biomass in a Fagus-Quercus forest, even though oak held $50 \%$ of the basal area and $46 \%$ of the total leaf area in the stand. Over-proportional reduction in fine root biomass of target tree species in mixed stands has also been reported by e.g. Hendriks and Bianchi (1995), Rust and Savill (2000), and Schmid and Kazda (2002) for stands including Pseudotsuga menziesii, Fraxinus excelsior and Picea abies. Most likely, these patterns are the outcome either of asymmetric root competition or of indirect competitive interactions involving unknown negative third-party effects on the roots of the inferior species.

A comparatively low belowground competitive ability of Quercus is strongly supported by the results of our root competition experiments. Even though we were not able to accommodate all treatments with a sufficient number of replicates, which partly reduced the statistical significance of the results, there was a tendency for Quercus roots to grow slower when placed with Carpinus, Fagus and Tilia roots than when growing with conspecific roots. This fits to the root abundance data indicating that Quercus root RGR tended to be reduced in the presence of competing Carpinus or Fagus roots. A high belowground competitive ability of Fagus in mixture with Quercus is supported by an earlier competition experiment with root growth chambers in a two-species Fagus-Quercus stand on sandy soil (Hertel and Leuschner 2006).

Although the root growth chambers employed here were designed to simulate fine root growth in a soil environment as close to nature as possible, several artefacts are inherent to this method, most notably an initial disturbance of the mycorrhizosphere (see discussion in Hertel and Leuschner 2006). The growth experiments may also be biased by temporal patterns of fine root growth that could differ between the competing species, thereby influencing the outcome of competition experiments (Eissenstat and Caldwell 1988; Burke and Chambers 2003). However, the long period of exposure (180-210 days) should have minimised this type of error in our experiment. Because the large majority of chambers showed vital fine root growth, resulting in largely overlapped root systems at harvest time, we believe that this method, if applied with a large number of replicates ( $>30$ per treatment), represents a promising approach to analyse root competition between trees with a statistically sound design in intact stands. Other approaches to study fine root growth in situ such as the minirhizotron technique (Hendrick and Pregitzer 1996; Majdi 1996) or walk-in rhizotron facilities (Atkinson 1985; Smit et al. 1994) are not suitable for investigating root competition because they do not allow root neighbourhood manipulation or are rarely large enough to accommodate mature trees.

Our empirical data are support for more recent spatial modelling studies and theoretical analyses which concluded that belowground competition should rather be asymmetric than symmetric when resources are distributed heterogeneously in the soil, thereby contradicting earlier assumptions on the outcome of root competition (Schwinning 1996; Schwinning and Weiner 1998; Bauer et al. 2004). For example, asymmetric root competition could take place where larger plants are able to occupy nutrient-rich soil patches (Van Lear and Kapeluck 1995). Indeed, Fagus and Carpinus, the two species with the largest total fine root biomass in the investigated stand, were the only trees species present in the organic layer. Furthermore, larger plants could have access to deeper soil water reserves and deplete them before smaller plants can gain access providing them with a disproportionate part of the soil resources (Robinson et al. 
1999). Asymmetry of competition for nutrients and water should increase when resource supply is high but uptake kinetics differ between the species (Raynaud and Leadley 2005). The yet existing evidence of asymmetric root competition is from herbaceous plants and not from mature trees, and it is contradicting (Blair 2001; Fransen et al. 2001; Cahill and Casper 2000; Facelli and Facelli 2002; Rajaniemi 2003; von Wettberg and Weiner 2003). Our data seem to be among the first to prove asymmetric belowground competition in forests. They are supported by sap flow measurements in small-diameter absorbing roots which indicated different water uptake rates by the roots of co-occurring tree species in a temperate mixed stand (S. Korn, D. Burk, and C. Leuschner, unpublished data).

Do the four tree species form a belowground competitive hierarchy?

We used the contrasting fine root growth rates in intra- and interspecific competition treatments as a measure of a species' belowground interspecific competitive ability. According to the classical Lotka-Volterra competition model, stable coexistence between a pair of species will occur if both species inhibit their own growth through intraspecific competition more than they inhibit that of the other species through interspecific competition. Accordingly, the root growth patterns of Fagus in the root chambers with a lower RGR in single-species chambers than in the two-species chambers must be judged as a clear indication of a superior belowground competitive ability of beech in this stand. Higher RGR of roots under interspecific competition may enable Fagus to occupy more soil space in mixture than in intraspecific constellations. On the other hand, it is likely that foraging for water and nutrients in Quercus and Carpinus is hampered by allospecific roots. Alternative measures of competitive ability such as overall plant fitness or total productivity are not applicable in root competition studies with tall trees, although they would be more consistent with the widely accepted standard of measuring competition effects on plants (Grace 1995). Our root growth-related approach yielded a species ranking with respect to competitive ability in the sequence Fagus $>$ Tilia $>$ Carpinus $>$ Quercus .

Accordingly, root competition is size-asymmetric with superior and inferior species in this stand. Recently, Tatarinov et al. (2008) have suggested that trees which are classified by their aerial parts as 'dominant' or 'suppressed' retain their social status belowground. Whereas the observed low competitive ability of Carpinus roots in this stand seems to match with the inferior position of this species in the second canopy layer of the stand, such an explanation is not valid in the case of Quercus which reveals a dominant habit aboveground according to tree height and leaf area (Table 1), but does not so belowground.

Our experiments do not allow conclusions on the underlying mechanisms of the observed belowground interaction. In theory, at least three mechanisms are possible. (1) Different species may differ in their surfacespecific water and/or nutrient uptake rates leading to resource pre-emption by the superior competitor (see the contrasting water uptake rates in trees discussed above, and Craine et al. 2005). (2) Unknown growth-reducing effects could act directly on the competitively inferior Quercus roots. (3) Self-self-discrimination could have occurred in the case of Fagus roots. Roots of the same species have been found to self-inhibit each other in certain herbaceous and shrubby species (Falik et al. 2003, 2005; Gruntman and Novoplansky 2004); this would lead to a lower growth rate in treatments with intra- compared to interspecific competition.

According to root biomass data in mono-specific and mixed Fagus/Picea forests, beech seems to be a superior competitor belowground not only in mixture with oak but also with spruce (Schmid and Kazda 2002). Hence, it appears that Fagus is a successful competitor belowground in a variety of Central European mixed forests, even though it is known that the competitive ability of a species can vary in dependence of the environment and the identity of the competing species. Moreover, in European beech, high belowground and aboveground competitive abilities seem to be linked to each other (Leuschner 1998) supporting Grime's (2001) hypothesis of a positive correlation between these two components of plant competition.

\section{Conclusion}

Our results show that, in this four-species stand, (1) the fine root systems of different tree species do not seem to be territorial but are broadly overlapping, (2) root competition between trees can clearly be asymmetric, and (3) tree species may be ranked according to their belowground competitive ability. Future experimental studies in the rhizosphere of forests have to reveal whether these findings apply to other mixed forests as well, and what mechanisms (including resource competition, self-self inhibition, facilitation, allelopathy, or indirect competitive interactions through other organisms or agents) underlie the observed root growth responses in the chambers.

Acknowledgments The authors are very grateful to Dietrich Hertel for fruitful discussion on the topic, and Mechthild Stange for her skilful support in the field. 
Open Access This article is distributed under the terms of the Creative Commons Attribution Noncommercial License which permits any noncommercial use, distribution, and reproduction in any medium, provided the original author(s) and source are credited.

\section{References}

Aikio S, Pakkasmaa S (2003) Relatedness and competitive asymmetry-implications for growth and population dynamics. Oikos 100:283-290. doi:10.1034/j.1600-0706.2003.11814.x

Ammer C (2003) Growth and biomass partitioning of Fagus sylvatica L. and Quercus robur L. seedlings in response to shading and small changes in the R/FR-ratio of radiation. Ann Sci 60:163171. doi:10.1051/forest:2003009

Atkinson D (1985) Spatial and temporal aspects of root distribution as indicated by the use of a root observation laboratory. Special Publ Br Ecol Soc 4:43-65

Atkinson D, Naylor D, Coldrick GA (1976) Effect of tree spacing on apple root-system. Hortic Res 16:89-105

Bais HP, Vepachedu R, Gilroy S, Callaway RM, Vivanco JM (2003) Allelopathy and exotic plant invasion: from molecules and genes to species interactions. Science 301:1377-1380. doi:10.1126/ science. 1083245

Barberis IM, Tanner EVJ (2005) Gaps and root trenching increase tree seedling growth in Panamanian semi-evergreen forest. Ecology 86:667-674. doi:10.1890/04-0677

Bauer S, Wyszomirski T, Berger U, Hildenbrandt H, Grimm V (2004) Asymmetric competition as a natural outcome of neighbour interactions among plants: results from the field-of-neighbourhood modelling approach. Plant Ecol 170:135-145. doi: 10.1023/B:VEGE.0000019041.42440.ea

Bédéneau M, Auclair D (1989) The study of tree fine root distribution and dynamics using a combined trench and observation window method. Ann Sci 46:283-290. doi:10.1051/forest:19890307

Blair B (2001) Effect of soil nutrient heterogeneity on the symmetry of belowground competition. Plant Ecol 156:199-203. doi: 10.1023/A:1012664431933

Bonanomi G, Giannino F, Mazzoleni S (2005) Negative plant-soil feedback and species coexistence. Oikos 111:311-321. doi: 10.1111/j.0030-1299.2005.13975.x

Burke MK, Chambers J (2003) Root dynamics in bottomland hardwood forests of the southeastern United States Coastal Plain. Plant Soil 250:141-153. doi:10.1023/A:1022848303010

Burkes EC, Will RE, Barron-Gafford GA, Teskey RO, Shiver B (2003) Biomass partitioning and growth efficiency of intensively managed Pinus taeda and Pinus elliottii stands of different planting densities. For Sci 49:224-234

Büttner V, Leuschner C (1994) Spatial and temporal patterns of fineroot abundance in a mixed oak beech forest. For Ecol Manag 70:11-21

Cahill JF, Casper BB (2000) Investigating the relationship between neighbor root biomass and belowground competition: field evidence for symmetric competition belowground. Oikos 90:311-320. doi:10.1034/j.1600-0706.2000.900211.x

Caldwell MM, Manwaring JH, Durham SL (1996) Species interactions at the level of fine roots in the field: influence of soil nutrient heterogeneity and plant size. Oecologia 106:440-447. doi:10.1007/BF00329699

Campbell BD, Grime JP, Mackey JML (1991) A trade-off between scale and precision in resource foraging. Oecologia 87:532-538. doi:10.1007/BF00320417

Coomes DA, Grubb PJ (2000) Impacts of root competition in forests and woodlands: a theoretical framework and review of experiments. Ecol Monogr 70:171-207
Craine JM, Fargione J, Sugita S (2005) Supply pre-emption, not concentration reduction, is the mechanism of competition for nutrients. New Phytol 166:933-940. doi:10.1111/j.1469-8137. 2005.01386.x

de Kroon H, Mommer L, Nishiwaki A (2003) Root competition: towards a mechanistic understanding. In: de Kroon K, Visser EJW (eds) Root Ecology. Springer, Berlin, pp 215-235

Eissenstat DM, Caldwell MM (1988) Seasonal timing of root-growth in favorable microsites. Ecology 69:870-873. doi:10.2307/1941037

Ellenberg H (1996) Vegetation Mitteleuropas mit den Alpen in ökologischer, dynamischer und historischer Sicht. Ulmer, Stuttgart

Escamilla JA, Comerford NB (1998) Measuring nutrient depletion by roots of mature trees in the field. SSSAJ 62:797-804

Espeleta JF, Eissenstat DM, Graham JH (1998) Citrus root responses to localized drying soil: a new approach to studying mycorrhizal effects on the roots of mature trees. Plant Soil 206:1-10. doi: 10.1023/A:1004325300583

Facelli E, Facelli JM (2002) Soil phosphorus heterogeneity and mycorrhizal symbiosis regulate plant intra-specific competition and size distribution. Oecologia 133:54-61. doi:10.1007/s00442002-1022-5

Falik O, Reides P, Gersani M, Novoplansky A (2003) Self/non-self discrimination in roots. J Ecol 91:525-531. doi:10.1046/j.13652745.2003.00795.x

Falik O, Reides P, Gersani M, Novoplansky A (2005) Root navigation by self inhibition. Plant Cell Environ 28:562-569. doi:10.1111/j. 1365-3040.2005.01304.x

Fargione J, Tilman D (2005) Niche differences in phenology and rooting depth promote coexistence with a dominant C-4 bunchgrass. Oecologia 143:598-606. doi:10.1007/s00442-0050010-y

Fransen B, de Kroon H, Berendse F (2001) Soil nutrient heterogeneity alters competition between two perennial grass species. Ecology $82: 2534-2546$

Grace JB (1995) On the measurement of plant competition intensity. Ecology 76:305-308. doi:10.2307/1940651

Grime JP (2001) Plant strategies, vegetation processes, and ecosystem properties. Wiley, Chichester, UK

Gruntman M, Novoplansky A (2004) Physiologically mediated self/ non-self discrimination in roots. Proc Natl Acad Sci USA 101:3863-3867. doi:10.1073/pnas.0306604101

Hendrick RL, Pregitzer KS (1996) Applications of minirhizotrons to understand root function in forests and other natural ecosystems. Plant Soil 185:293-304. doi:10.1007/BF02257535

Hendriks CMA, Bianchi FJJA (1995) Root density and root biomass in pure and mixed forest stands of Douglas-fir and beech. Neth J Agric Sci 43:321-331

Hertel D (1999) Das Feinwurzelsystem von Rein- und Mischbeständen der Rotbuche: Struktur, Dynamik und interspezifische Konkurrenz. Cramer, Berlin

Hertel D, Leuschner C (2006) The in situ root chamber: a novel tool for the experimental analysis of root competition in forest soils. Pedobiologia (Jena) 50:217-224. doi:10.1016/j.pedobi.2005.11.002

Hölscher D, Hertel D, Leuschner C, Hottkowitz M (2002) Tree species diversity and soil patchiness in a temperate broad-leaved forest with limited rooting space. Flora 197:118-125

Holzapfel C, Alpert P (2003) Root cooperation in a clonal plant: connected strawberries segregate roots. Oecologia 134:72-77. doi:10.1007/s00442-002-1062-x

Hutchings MJ, John EA (2004) The effects of environmental heterogeneity on root growth and root/shoot partitioning. Ann Bot (Lond) 94:1-8. doi:10.1093/aob/mch111

Jackson RB, Caldwell MM (1993) The scale of nutrient heterogeneity around individual plants and its quantification with geostatistics. Ecology 74:612-614. doi:10.2307/1939320 
Johnsen KH, Maier C, Kress L (2005) Quantifying root lateral distribution and turnover using pine trees with a distinct stable carbon isotope signature. Funct Ecol 19:81-87. doi:10.1111/j. 0269-8463.2005.00928.x

Kochenderfer JN (1973) Root distribution under some forest types native to West-Virginia. Ecology 54:445-448. doi:10.2307/ 1934355

Korn S (2004) Experimentelle Untersuchung der Wasseraufnahme und der hydraulischen Eigenschaften des Wurzelsystems von sechs heimischen Baumarten. PhD thesis. University of Goettingen, Germany. http://webdoc.sub.gwdg.de/diss/2004/korn/ korn.pdf

Leuschner C (1998) Mechanismen der Konkurrenzüberlegenheit der Rotbuche. Ber Reinhard-Tuxen-Gesellschaft 10:5-18

Leuschner C, Hertel D, Coners H, Büttner V (2001) Root competition between beech and oak: a hypothesis. Oecologia 126:276-284. doi:10.1007/s004420000507

Leuschner C, Hertel D, Schmid I, Koch O, Muhs A, Hölscher D (2004) Stand fine root biomass and fine root morphology in old-growth beech forests as a function of precipitation and soil fertility. Plant Soil 258:43-56. doi:10.1023/B:PLSO. 0000016508.20173.80

Łomnicki A (1980) Regulation of population-density due to individual-differences and patchy environment. Oikos 35:185-193. doi: $10.2307 / 3544426$

Ludwig F, Dawson TE, Prins HHT, Berendse F, de Kroon H (2004) Below-ground competition between trees and grasses may overwhelm the facilitative effects of hydraulic lift. Ecol Lett 7:623-631. doi:10.1111/j.1461-0248.2004.00615.x

Lyford WH, Wilson BF (1964) Development of the root system of Acer rubrum L. Harv For Pap 10:1-17

Mahall BE, Callaway RM (1991) Root communication among desert shrubs. Proc Natl Acad Sci USA 88:874-876. doi:10.1073/ pnas.88.3.874

Majdi H (1996) Root sampling methods-applications and limitations of the minirhizotron technique. Plant Soil 185:255-258. doi: 10.1007/BF02257530

Mamolos AP, Elisseou GK, Veresodlou DS (1995) Depth of root activity of coexisting grassland species in relation to $\mathrm{N}$ and $\mathrm{P}$ additions, measured using nonradioactive tracers. J Ecol 83:643652. doi: $10.2307 / 2261632$

Mou P, Jones RH, Mitchell RJ, Zutter B (1995) Spatial-distribution of roots in Sweetgum and Loblolly pine monocultures and relations with aboveground biomass and soil nutrients. Funct Ecol 9:689_ 699. doi:10.2307/2390162

Nagel J, Schmidt M (2006) The silvicultural decision support system BWINPro. In: Hasenauer H (ed) Sustainable forest management, growth models for Europe. Springer, Berlin, pp 59-63

Nambiar EKS, Sands R (1993) Competition for water and nutrients in forests. Can J Res 23:1955-1968. doi:10.1139/x93-247

Nielsen CCN, Mackenthun G (1991) Die horizontale Variation der Feinwurzelintensität in Waldböden in Abhängigkeit von der Bestockungsdichte. Allg Forst Jagdz 162:112-119

Nobel PS (1997) Root distribution and seasonal production in the northwestern Sonoran desert for a C3 subshrub, a C4 bunchgrass, and a CAM leaf succulent. Am J Bot 84:949-955. doi:10.2307/ 2446285

Parrish JAD, Bazzaz FA (1976) Underground niche separation in successional plants. Ecology 57:1281-1288. doi:10.2307/ 1935052

Rajaniemi TK (2003) Evidence for size asymmetry of belowground competition. Basic Appl Ecol 4:239-247. doi:10.1078/14391791-00151
Rajaniemi TK, Allison VJ, Goldberg DE (2003) Root competition can cause a decline in diversity with increased productivity. J Ecol 91:407-416. doi:10.1046/j.1365-2745.2003.00768.x

Raynaud X, Leadley PW (2005) Symmetry of belowground competition in a spatially explicit model of nutrient competition. Ecol Modell 189:447-453. doi:10.1016/j.ecolmodel.2005.03.008

Robinson D, Hodge A, Griffiths BS, Fitter AH (1999) Plant root proliferation in nitrogen-rich patches confers competitive advantage. P R Soc Lond B Bio 266:431-435. doi:10.1098/rspb. 1999.0656

Rust S, Savill PS (2000) The root systems of Fraxinus excelsior and Fagus sylvatica and their competitive relationships. Forestry 73:499-508. doi:10.1093/forestry/73.5.499

Schenk HJ (2006) Root competition: beyond resource depletion. J Ecol 94:725-739. doi:10.1111/j.1365-2745.2006.01124.x

Schenk HJ, Callaway RM, Mahall BE (1999) Spatial root segregation: are plants territorial? Adv Ecol Res 28:146-180

Schipka F (2002) Leaf water relations and stand transpiration of four beech forests across a precipitation gradient in Central Germany (In German). PhD thesis, University of Göttingen

Schmid I, Kazda M (2002) Root distribution of Norway spruce in monospecific and mixed stands on different soils. For Ecol Manag 159:37-47

Schwinning S (1996) Decomposition analysis of competitive symmetry and size structure dynamics. Ann Bot (Lond) 77:47-57. doi:10.1006/anbo.1996.0006

Schwinning S, Weiner J (1998) Mechanisms determining the degree of size asymmetry in competition among plants. Oecologia 113:447-455. doi:10.1007/s004420050397

Smit AL, Groenwold J, Vos J (1994) The Wageningen Rhizolab—a facility to study soil-root-shoot-atmosphere interactions in crops. 2. Methods of root observations. Plant Soil 161:289298. doi:10.1007/BF00046400

Stout BB (1956) Studies of the root system of deciduous trees. Black Rock For Bull 15:1-45

Tatarinov F, Urban J, Čermák J (2008) Application of "clump technique" for root system studies of Quercus robur and Fraxinus excelsior. For Ecol Manage 255:495-505

Thomas SC, Weiner J (1989) Including competitive asymmetry in measures of local interference in plant populations. Oecologia 80:349-355. doi:10.1007/BF00379036

Tierney GL, Fahey TJ (2001) Evaluating minirhizotron estimates of fine root longevity and production in the forest floor of a temperate broadleaf forest. Plant Soil 229:167-176. doi: 10.1023/A:1004829423160

Van Lear DH, Kapeluck PR (1995) Above- and below-stump biomass and nutrient content of a mature Loblolly pine plantation. Can J Res 25:361-367. doi:10.1139/x95-040

Van Praag HJ, Sougnezremy S, Weissen F, Carletti G (1988) Root turnover in a Beech and a Spruce stand of the Belgian Ardennes. Plant Soil 105:87-103. doi:10.1007/BF02371146

von Wettberg EJ, Weiner J (2003) Larger Triticum aestivum plants do not preempt nutrient-rich patches in a glasshouse experiment. Plant Ecol 169:85-92. doi:10.1023/A:1026253007056

Weiner J, Wright DB, Castro S (1997) Symmetry of below-ground competition between Kochia scoparia individuals. Oikos 79:8591. doi: $10.2307 / 3546093$

Wilson JB (1988) Shoot competition and root competition. J Appl Ecol 25:279-296. doi:10.2307/2403626

Yokozawa M, Kubota Y, Hara T (1998) Effects of competition mode on spatial pattern dynamics in plant communities. Ecol Modell 106:1-16. doi:10.1016/S0304-3800(97)00181-6 